\title{
WRITING A FOLKLORIST'S PERSONA IN THE FIELD: HOW DEFINING THE OBJECT OF STUDY DEFINES THE SCHOLAR
}

\author{
LiSA SVANFELDT-WINTER
}

\section{ABSTRACT}

In this article, I approach negotiations of belonging by studying the relationship between folklorists and their informants. I examine how young Finnish folklorists on their first collection journeys in the early 1920s positioned themselves as scholars by stressing both their identification with and their differences from the informants. The discipline's high status as a "national science" required the collectors to approach the locals as carriers of a national heritage shared between the collectors and informants. On the other hand, the pursuit of scholarly acknowledgement urged the scholars to emphasize their position as experts who could evaluate the authenticity and academic relevance of the information offered by the locals. One effective way to do so was to highlight a temporal distance between the describer and the described, placing the informants in an earlier time of lower social and cultural development than the scholar. I discuss how the alternation between identification and difference can be interpreted as a means for the scholars to negotiate their places in their academic community and to form feasible scholarly personas within it. The article places special focus on how the young collectors performed this negotiation by describing informants in their correspondences with student friends and cooperating to find shared ways of approaching the informants in acceptable ways according to their discipline.

\section{KEY WORDS}

Scholarly Persona; History; Nationalism; Ethnography; Folklore Collections

\section{INTRODUCTION}

Research on the histories of scholarly personas has given us exciting insights into how culturally and socially bound expectations affect who could participate in research and academic debate and the consequences this selection of participants has had on what knowledge is produced and accepted as relevant and true (Daston \& Sibum 2003; Paul 2016; Bosch 2013). The aim of this article is to contribute to these discussions by asking how objects of study were used in persona formation. I argue that the object of study is a prerequisite for scholars to do their work and thus for scholarly personas to exist. Where would the historian be without sources or the botanist without flora? Still, the relationships with the objects of study have not been given much attention in research on scholarly personas. I approach the matter by discussing how Finnish students of folklore in the field, 
the countryside in the 1920s, described the locals, their objects of study. By writing letters to each other about the locals and so positioning themselves in relation to them, the students tried out and negotiated their scholarly personas.

\section{FOLKLORISTICS AND THE FINNISH CONTEXT}

The discipline of folkloristics examines immaterial culture, such as beliefs, proverbs and songs. Folkloristics had and still has somewhat fluid borders to related disciplines, such as anthropology, ethnology and language and literature studies. It developed as an academic discipline during the nineteenth century, in close connection with the national romanticist and nationalist movements. For a long period, the primary focus remained on collecting and studying folk culture within the scholars' own nations, and the field gained relatively high status in many countries since it was used to demonstrate a nation's traditional, unique, and civilized culture. This was particularly the case in many new states with little political history to build national pride on (Baycroft 2012, pp.3-5; Ó Giolláin 2000, pp.4, 76-77). To this end, researchers strove to find the most archaic folklore they could, agreeing upon that this information had survived most untouched among the elderly in the countryside. The material for research was to a large extent collected by scholars, students and amateur collectors who travelled the countryside and interviewed locals about their dialects and proverbs, oral poetry and beliefs (ó Giolláin 2000, pp.50-51).

Finland was one such typical new state in the beginning of the twentieth century. The territory was part of Sweden until 1809, when it was lost to Russia and gained status as an autonomic Grand Duchy. During the autonomic period, the intelligentsia followed the national romanticist ideas of finding and bringing forward a national self-awareness. When Russian rule towards the end of the century moved from extensive autonomy and cultural heterogeneity within its realm towards so-called Russification politics, this newly "found" national culture was used in the resistance to these politics. In 1917 amid the turmoil of the Russian Revolutions and the First World War, Finland claimed independence. A four-month-long civil war between socialists and conservatives followed and was eventually won by the conservatives. It was in this context that the Finnish folklorists were working with finding the "authentic" culture of the Finns (Anttonen 2012, pp.336-228).

The Finnish case is not only interesting in national history-writing but also gives broader insights. The Finnish folklorists were at the centre of developing the historicgeographic method, also called the Finnish School, which was a dominant approach to folklore scholarship at the time (Seljamaa 2008, p.85). Although Finland's location was rather provincial, the scholars' ways of being folklorists were not without significance. Folklorists' participation in the nation-building project was also not exclusively a Finnish phenomenon and corresponded to parallel circumstances in others parts of Europe.

\section{APPROACHES TO STUDYING A FOLKLORIST'S PERSONA}

I use H. Otto Sibum and Lorrain Daston's general definition of persona as an intermediate concept between individuals and institutions as a point of departure, which allows for the study what it takes to be a good, acknowledged scholar in academic communities bound to time, place and scholarly field (Daston \& Sibum 2003, pp.2-4). I view the function of persona through the lens of Conal Condren, Stephen Gaukroner and Ian Hunter's work, who argue that persona functions as an office, a position from which the scholar acts and speaks as a scholar and with the authority of a scholar. The office or persona offers individuals authority but comes also with a framework for what is suitable and possible within its parameters. A feasible persona, they 
argue, authenticates scholars' arguments. In their interpretation, scholars purposely form themselves - construct a persona-in order to adapt to the expectations of their field (Condren, Gaukroger \& Hunter 2006, p.10). In order to study how this forming happens, I use Mineke Bosch's approach of persona formation as a performative process which can be linked to Judith Butler's theory of how gender is made by repetitions that create and confirm identity and norms (Bosch 2013, p.17; Butler 1999, pp.42-44).

Previous research on the scholarly persona has often focused on scholars in single disciplines, just as I do here (See e.g. Carson 2001; Paul 2017; Tai \& Dongen 2016). What would one more study of one more discipline-and a very small one-give us that has not yet been discovered? I argue that this small, even peripheral, discipline offers us a new perspective by letting us study how scholarly personas were constituted in relation to the scholars' objects of study. Inspired by the Finnish folklorist Jyrki Pöysä's interpretation that "essentially, the field is not a place, but the relationship between the researcher and the people put into objects of study"(Pöysä 2004, p.25), I discuss how this relationship out in the field shaped the folklorists' personas. The active role of the informants made them visible and an object of debate within the discipline. Similar to contemporary historians, who critically evaluated (and to a large extent discarded) the validity of their sources, folklorists discussed not only how to choose informants in order to gain valid information but also how to approach and interview them (Lilja 1996, p.240; Fabian 2006, p.143). However, in order to remain authorities over folkloristic knowledge, the scholars needed to assert control over the information provided by the informants, who could, intentionally or unintentionally, change the access to and the extent of the information provided as well as the content itself. Folklorists also observed that the informants could act differently depending on how they felt about the collectors; for example the collector's dialect, gender or appearance could affect the outcome of the interviews (Kallio 2013, pp.59-60). Informants were even known to criticise the scholars' interpretations or share their information with a larger audience without using the researcher as an intermediary (Tarkka 1989, pp.247-248).

I wish to approach this relationship by studying how students described the people in the countryside and how they, by the performance of writing these accounts and repeating certain models of being a good scholar, manifested and formed personas. Inspired by Condren, Gaukroner and Hunter, I look at how the students pursued positions that would give them authority to speak as folklorists and what was used to authenticate the folklorists' arguments. When reading the sources, patterns can be identified with the help of three theoretical approaches that have had great impact on (critical) folklore studies.

The first is Regina Bendix's work on authenticity. Authenticity holds a special place within folklore studies. The collectors and scholars of the discipline's early years hunted for the authentic folk culture, just as their colleagues in, for example, anthropology intended to map authentic culture in exotic places (Bendix 1997, pp.5, 95-96; compare Junkala et al. 1998, p.68). When something is declared authentic, it gains the status of being worthwhile to archive and analyse. At the same time, making a declaration of authenticity can legitimize the person declaring it. In most cases, authentic folklore equalled archaic culture, which was the most highly valued information (Bendix 1997, p.7; compare Dundes 1980, pp.2-5; Koski 2011, pp.3839). According to Bendix, folklorists accentuate scholarly authority by claiming a position that allows them to judge what information should be considered authentic folklore (Bendix 1997, p.7). I use this approach to examine how the folklore students used descriptions of authenticity as a means for manifesting themselves as folklorists. 
The second is Johannes Fabian's work on anthropologists' making of the objects of study as their Other. Fabian claims that anthropologists create their objects of study by systematically placing the observed in another time than the observer, which creates a distance and difference between them, a tendency that he calls the denial of coevalness. It positions the observer as a modern creature, while the observed lives in a supposed older time and is thus more primitive. This makes it possible for the observer to claim a position from where they can analyse the information given (Fabian 2002, pp.25, 31-32). Fabian's work is rooted in a larger postcolonial critique of the ethnographic disciplines, which gained in strength during the 1980s. This critical tradition claimed that the disciplines' knowledge was produced by understanding and presenting its objects of study as counter-images of the scholars' cultures (Said 2000, pp.110113, 120, 130; Loomba 2002, p.48; Clifford \& Marcus 1986, pp.4-5; Boon 1982, pp.vii-xvii).

Both the approach of the folkloristic search for archaic (authentic) culture and Fabian's theory take as a premise that the practice of describing cultural traits from a time that the describer did not belong to gave scholarly authority. At the same time, the nationalistic foundation of folkloristics adds an element of conflicting interest for the scholars, which brings us to the third approach: As one key motivation for folklore research was to save what was left of an ancient national heritage, to a certain degree, the scholars needed identify themselves with their objects of study (Anttonen 2005, p.148; Spring 2001, pp.80-81). When searching for what constituted the folklorist's persona, this creates an interesting tension. On the one hand, the scholars manifested their scholarly authority by distancing themselves from the objects of study. On the other hand, the function of their discipline as a tool in the nation-building project - which also brought the discipline much of its status - urged them to identify themselves with the same objects (Bendix 1997, p.49). This tension further reminds us of the strong impact of nationalism in this context. However, this article is not primarily a study in nationalism but in how scholarly personas are shaped. Nonetheless, as folkloristics was embedded in the nation-building project, it must be viewed as an inherent component of the folklorist's persona of the time and is therefore also part of the empirics and analysis in this study.

In this article I ask how two students in the field described local people and circumstances and how they expressed their own personas as aspiring folklore scholars. I study how they positioned themselves as the legitimate observers and describers of the people and culture, while simultaneously having to stress that they themselves were describing their own national culture. Building particularly on these three approaches, I examine how the young folklorists alternated between describing their own cultural heritage and stressing their differences from their objects of study. I argue that this alternation can be viewed as a means of negotiating their places as scholars in a nationalistically-driven discipline as well as a construction of a scholarly persona as it develops from a student to a researcher persona.

\section{CASES AND SOURCES}

To address the questions posed above, I use personal documents written by two folklore students in Finland during the 1920s: Elsa Enäjärvi (1901-1951) and Martti Haavio (18991973). They were both from middle-class backgrounds, originally from rural areas. They earned BA degrees in folkloristics in 1921 and 1923 respectively, and continued from there with PhDs and academic careers. Typically for the students and scholars of their time and field of study, they participated in right-wing nationalist associations and cultural societies. After several years of friendship, dating and collegial camaraderie, Enäjärvi and Haavio got married in 1929 (Sievänen-Allen 1993, pp.9-10, 116-119, 388, 392; Majamaa n.d.; Eskola n.d.).The documents used in this study consist of diary notes and private letters to family and friends, all from 
personal collections archived at the Literary Archives of the Finnish Literature Society in Helsinki. I have left out sources such as newspaper articles, the material sent to the funding organisations' archives and letters of more formal character because they contain much less in terms of personal accounts of the students' relationships with their informants.

Haavio and Enäjärvi wrote a majority of the documents used as sources here on the Finnish countryside between 1921 and 1924. In 1921, Haavio made a month-long fieldwork journey to South Karelia in southeastern Finland on a scholarship from the Finnish Literature Society. Enäjärvi, again, spent five weeks in 1924 in her childhood village, Vihti, where she collected proverbs and dialectal words for the Dictionary Foundation (Fi. Sanakirjasäätiö). In the summer of 1923, both took a long journey to North Karelia. The journey was organised by the right-wing nationalistic Academic Karelia Society (Akateeminen Karjalaseura, AKS), and the aim was to "enlighten" people in line with the Karelianistic ideology. The ideology embraced vernacular culture in the border region of Karelia. The region was considered to have preserved the last pieces of an archaic Finnish culture, mainly thanks to its peripheral location and many rather isolated localities. It was also the region where the Finnish scholar Elias Lönnrot (18021884) had collected folk poetry for the national epic Kalevala, which further strengthened the region's status as a treasury of folk culture. For that reason, it engaged many scholars, especially in the humanities, as well as common people and artists. Besides the romanticising gaze on Karelian landscape and people, the movement also had a political, irredentist side, supporting the fights for independence by Karelians on the Soviet side of the border and promoting Finnish annexation of Soviet territory inhabited by Finnic people (Fewster 2011, pp.38-39; Virtanen 2001, pp.135-141). During the AKS tour, the students visited towns and villages where they propagated the society's agenda, but they also made small excursions in national romantic landscapes, swam, and held parties on their own. The purpose of the journey was not to collect folklore, but I have included the texts written during this time because they describe the locals in the same way as they are described during collection journeys. In other words, the relationship between the describer and the described or the observer and the observed seems to have been the same in these descriptions as in descriptions of informants.

\section{NATIONAL LANDSCAPES AND PEOPLE}

The students' letters and diaries radiate enthusiasm for being out in the countryside, observing and describing the locals. The students describe an eagerness to participate in the larger project of collecting and promoting Finnic culture, to which their fields of study were so tightly connected. The students biked through national romantic landscapes encountering helpful locals and knowledgeable informants of Finnish and Finnish-related origin.

When describing the landscape, Enäjärvi's and Haavio's accounts mirror the observations that previous research has made on how nationalistically minded ethnographers tended to describe their national landscape. In the Finnish context, that meant birches, forested pinewood hills, glittering blue lakes, grazing domestic animals, fields and cottages. Although urban imaginings were more frequently published during the nineteenth and early twentieth centuries, rural landscapes were long considered to be the most typical national imaginings of Finnishness (Häyrynen 2000, pp.9-10; LCMH 730 (2:3:15); MCMH 5.1, (7.6.1921); Eskola 1999, p. 179; LCMH 758 (23:6:1)). In that sense, we can read Enäjärvi's and Haavio's landscape descriptions as ways of portraying their surroundings in a stereotypical national way.

The descriptions of the landscape were predominantly positive, radiating the same enthusiasm as other accounts of the fieldwork journeys. Enäjärvi and Haavio also wrote of a picturesque landscape with enjoyable weather conditions. This did not necessarily exclude rain, 
cold and thunder from the travel letters, but these elements did not appear in connection to remarks of the landscape (LCMH 736 (8:4:1-2); LCEEH 785 (13:10:25); Eskola 1999, pp.175178,321 . By exclusively connecting good weather with the national landscape, the students reinforced its idyllic aura, filling what was popularly considered their "own" landscape solely with idealizing content.

One way of looking at the students' mirroring of a common rhetoric among nationalistically minded educated people is that the students wished to be included in that group and thus adapted to its jargon. However, I argue that the common rhetoric reflects more active agency. Tricia Cusack, who has studied imaging of "authentic" Irishness, argues that the repetition of imaging functioned as a reinforcement for painters and travel letter writers in search of folk roots (Cusack 2001, p.224). A student repeating the same descriptions of scenery as they can be assumed to have read and heard about before in similar contexts would not only follow an established writing tradition but also allow them to participate in the consolidation of the imaging. In terms of scholarly persona, they demonstrated adjustment to models of how to be a folklorist and this performance reproduced the folklorist's persona (Bosch 2013, pp.17, 22).

In comparison to the landscapes, the descriptions of people were more versatile. Recurring positive descriptions of the people in general were that they were friendly and kind (LCMH 731 (3:2:2); LCEEH 764 (1:7:1); 785 (13:10:25); MHEEH 5, 8.7[.1923]). For the travelling collectors, it was also a great advantage when the people were generous and hospitable, helping them with their work and transportation, repairing shoes and offering food and accommodation (LCMH 731 (3:2:2, 3:10:4); LCEEH 764 (1:8:1; 1:9:1); MCEEH 5, 12.7.1923; Eskola 1999, p.321). Other positive features included resilience and vividness ( LCMH 731 (3:10:3); LCEEH 785 (13:10:25); MCEEH 5, 8.7[.1923]; LCEEH 764 (1:8:1)). An interesting feature in Enäjärvi's accounts is that she wrote positively about all persons whom she in some way marked as having some form of higher status. The person could be the patron or matron of a house, a priest or a local leader. Still, no characteristics were solely used for the people of rank, and any of the people in the documents could be described as friendly, generous or vivid. The main difference was that when the social rank was marked, the descriptions were almost exclusively positive. Consequently, the persons with relatively higher social status received comparatively more positive descriptions than the others (LCEEH 764 (1:8:1); MCEEH 5, 8.7[.1923], 12.7.1923; LCEEH 785 (13:10:26)). When the students gave positive remarks of the locals, they repeated the identifying and idealising rhetoric of the nation and its people, the approach to national heritage that combined their political convictions and their discipline's greater aim. In this way, they manifested the politically coloured folklorist's persona.

If the people of rank evoked positive descriptions of places they recognized, smaller rural societies as wholes could be marked as particularly different from the students by being described as "uncivilized" (Fi. sivistymätön) and "primitive" (Fi. primitiivinen) (LCMH 731 (3:2:2, 3:10:6); LCMH 730 (2:4:10); LCMH 758 (23:4:1); LCEEH 764 (1:8:1); LCMH 736 (8:4:2)). These words were mainly used to describe communities or other larger entities, while individuals would instead be described as "sophisticated" (Fi. sivistynyt)(MCEEH 5, 8.7[.1923]). Haavio could, for example, tell his old friend and later colleague Lauri Hakulinen (1899-1985) that he was travelling to the municipality of Salmi and its surroundings, and that it "almost scares me to go there, being surrounded by those barbarians, so far from the civilized” (LCMH 731 (3:2:2)). He wrote this account when he was in Sortavala, a town on the northwest shore of Lake Ladoga. Salmi lies some 80 kilometres east of the town, next to the Soviet border. The geographical distance between Sortavala and Salmi is rather short, but the former apparently was more "civilized". The cultural distance might very well in Haavio's view have been greater; the former 
was a relatively bustling town with upper secondary schools and a seminar for teachers' education, shops and a Lutheran majority, while the latter was a small municipality with few possibilities for education and an Orthodox majority ('Tietosanakirja' 1922, pp.662-663, 16331638). According to Finnish historian Maria Lähteenmäki, the localities closest to the Russian border on the Karelian Isthmus were commonly considered exotic among Finnish visitors. Maybe Salmi, which also lies next to the border, but north of Lake Ladoga, had a similar exotic connotation for Haavio (Lähteenmäki 2009, pp.28-29).

Although Haavio's statement about Salmi does not sound particularly positive, low levels of education or differences from the collectors did not necessarily need to be described negatively. This is exemplified in Enäjärvi's diary note about the people of Taipale in North Karelia, who were, in her words, "the smartest we have met so far on our journey" (MCEEH 5, 8.7.1923). According to her, this could be explained by a relatively high standard of living based on good farming, and that the locality at the same time was "for the time being still protected from smugness and arrogance by the locality's status, which is not yet a village"(MCEEH 5, 8.7.1923). This statement indicates that being "smart" did not necessarily have the same meaning when referring to educated, urban people and to uneducated, rural people. The term seemed to indicate quite the opposite: by pointing out that the locality so far had been protected from negative influences by being small and isolated enough to not even be categorized as a village, Enäjärvi placed herself in a position from where she could evaluate the locality's authenticity and unspoiled nature.

Following Fabian, both primitivism and unspoiltness are means of creating the folklorists' othered study object. When the students described the locals as primitive, uncivilised or not affected by modernity, they created their Other, who-if the collector was lucky - was still carrying traits of an archaic national heritage. In a postcolonial understanding, they further manifested themselves in relation to their Other (e.g. Loomba 2002, p.48). In this self, I believe that we can see some of the folklorist's persona. In contrast to the object, the scholar quite naturally is modern, educated and civilized (Anttonen 2005, pp.28, 49). The practice itself of defining what constituted the people (the "folk" in folkloristics) was a way of defining oneself as scholar (Sääskilahti 1998, pp.66-67; Fabian 2002, p.25; Anttonen 2005, p.139; Vakimo 2001, p.26). In their accounts, Enäjärvi and Haavio showed their peers, themselves and their families that they qualified as folklorists, enough so to identify and analyse their objects.

\section{CELEBRATED FINNISHNESS AND DELETERIOUS RUSSIAN INFLUENCES}

After the students identified and described their objects of study, the carriers of Finnish and Finnic culture, they needed to demonstrate further their expertise and membership in their academic community by showing that they knew what this Finnishness entailed. In the sources, a common measure of Finnishness was the degree of Russian influence. This becomes particularly visible in the accounts from Karelia. Partly, this characterization was likely a result of the political aim of the journey. It also demonstrates the special status of Karelia as having a long history in the crossfire between Swedish and Russian cultural impact which called for scholars to distinguish archaic Finnish from Swedish/West European and Russian/East European features in the folk culture they collected (Fewster 2011, pp.31, 48-49; Apo, StarkArola \& Nenola 1998, p.16). Enäjärvi's and Haavio's searches for traces of "original" Finnishness were not limited to recordable manifestations of folk culture. The traces could also be observed in the way they described the locals particularly when they praised people for embodying what they considered distinguishable Finnish or Finnish-related qualities; in contrast, the two took a highly critical stance toward whatever they considered alien to Finnishness. In practice, these 
negative factors equalled Russian influence in their accounts, and, typically for their right-wing political peers, they used an anti-Russian rhetoric.

One recurring feature in the descriptions was references to Karelia as a border zone between two cultural spheres - the West and the East. This was clear, for example, when Enäjärvi refers to the area as "those poor border regions!" (LCMH 736 (8:4:2)), or in Haavio's locating his place of writing as "the most distant corner, where civilized social structure extends to the east" (LCMH 731 (3:10:6)). These statements clearly marked the writers' positionings as the civilized West against the uncivilized East. The border region in North Karelia, where Haavio and Enäjärvi made their statements, had indeed rather poor inhabitants and a low level of industry. In practice, however, this was true for several other Finnish regions, where agriculture was still the dominant livelihood and infrastructure in the 1920s. However, according to Anttonen, Finnish folklorists were keen to emphasise the poor conditions of Karelia. In this way, they manifested the difference between "their" (urban) Finland and Karelia, the treasury of archaic Finnishness. Similarly, Karelians were categorised as living within nature and tradition, while Finns lived within culture and history (Anttonen 2005, p.139).

The observations of Finnish and Russian traits in the travel accounts are not necessarily either/or, but, rather, spread over a scale stretching between these two trait categories. On the scale's far end of Finnishness, we can find a description of a people outside Finland's territory, the Ingrians. Haavio came across Ingrians in South Karelia, where they were queuing to formally immigrate to Finland. In Finland, they were referred to as refugees, since many had fled the Russian Federal Soviet Republic after being defeated in fights for independence after the October Revolution, while others fled the fights and mobilisations of World War I and were therefore referred to as refugees in Finland (Lähteenmäki 2009, pp.205-206, 213-215; Nevalainen 1991, pp.242, 247). For the folkcultural archives, the immigration was a good opportunity to collect Finnic material and so they sent collectors, Haavio being one of these, to the border. In Haavio's telling, the Ingrians were "the cream of the Finnish people"(LCMH 731 (3:2:2)). Other people could be described as Finnish but partly influenced by Russia. A North Karelian vicarage, in which the "Russki peeked from behind the order of the house and the children's Savo-Karelian dialect”(MCEEH 5, 8.7[1923]) expressed this Russian slant.

When referring to anything Russian or Soviet, Enäjärvi and Haavio used almost without exception the word "ryssä", for which I here use the translation "Russki" ('Russki' 2018). The term was especially frequently and disparagingly used in the 1920s by the anti-Russian movement (Keiho 1994). Also, it was commonly used when referring to the Orthodox Church, which was a faith much more common among the Karelians than the rest of the Finnish population. The term had a pejorative tone by the 1920s and we have considerable evidence that Enäjärvi and Haavio embraced right-wing anti-Russian ideas and thus used the term quite consciously. However, what we only can speculate upon is the degree to which we should read every use of "ryssä" to describe a person, object or phenomenon as a negative remark; or perhaps it was a way of marking their position in and currency with the anti-Russian discourse. For example, should the naming of a Karelian Orthodox priest as a "Russki priest" (LCMH 731 (3:1:13)) be read as a negative account of all Eastern influences or should we see it merely as the writer's choice to use the degrading word anywhere it could be deployed? At minimum, we can see in Enäjärvi's documents that Haavio's choice of words was not the only possible one within their circles. In place of Haavio's "Russki” characterization, Enäjärvi used the expression "the Greek Catholic Church", which, in the beginning of the twentieth century, usually still referred to the Greek Orthodox Church, although the meaning later shifted to refer to Catholic churches in Eastern Europe ('Finto: KOKO: ortodoksinen kirkko' n.d.; Forsman et al. 1925, p.735). This more correct term did not necessarily mean that it she was positioning her 
description in a much more positive context; it is more accurate to say that she used that term rather unflatteringly to characterize the village of Hattuvaara - in her words, a "Greek Catholic primitive village" (LCEEH 764 (1:8:1)).

Haavio's accounts about the people of Sosnovo (Fi. Rautu) also speak to the students' descriptions to a large extent reflecting an antipathy for most things Russian more than an academic quest detached from political conviction. Sosnovo was a Finnish locality close to the Russian/Soviet border until it was ceded to the Soviet Union in 1944. Haavio called the people "traitors, reptiles, beggars, smugglers and gulashs" (LCMH 731 (3:2:2)). The term gulash referred to black marketers but could be used for any workers in shady business (Nyström 2013, p.83). In the Finnish civil war, the socialist side in Sosnovo had been heavily backed by Russians, and the battles there had been particularly bloody. Eventually, the conservatives, for whom Haavio had been fighting in Southwest Finland, won both Sosnovo and the entire war (Lähteenmäki 2009, pp.120-121). Presumably, Haavio's critical stance toward the Sosnovo was coloured by the war circumstances, or at least he did not specify upon what else he would have based this judgement. If this personal circumstance shaped his judgement in any way, it would make the description and statements a result of political opinions rather than because of his understanding of folk culture. Nonetheless, related political perspectives have to be seen as relevant when exploring scholarly personas in folkloristics. Previous research has shown how folklore studies in Europe were very closely bound to right-wing politics and nation-building pursuits. In the Finnish case, this political affinity meant, to a large degree, an evident distancing from primarily (Soviet) Russia and secondarily Sweden and instead emphasising a distinct Finnish heritage (Baycroft 2012, pp.1-2; Garberding 2012, p.25; Anttonen 2012, pp.337-338). In this light, Haavio's anti-Russian and anti-socialist statements illustrate how these were commonly combined in a Finnish folklorist's persona. His and Enäjärvi's remarks on the Russian presence as parallel to an uncivilized and negative influence further illustrate how the folklorists did not only other their objects of study. In this case, the immediate Other identified in their descriptions was an intruder on the national self. A good folklorist would, in this sense, be able to separate between the Finnic (identifiable) and Russian (alien) elements in folk culture.

The tendency to determine the degree of Finnishness by contrasting it against Russian features found an exception in Haavio's comments on the Olonets Karelians. Olonets Karelia (Fi. Aunuksen Karjala) lies east of Lake Ladoga. The people mainly spoke Livvi which, in the 1920s, was referred to as a dialect branch of Karelian but is today usually categorised as a separate language ('Karjala' 2015). Haavio, too, recognized the difference between the Olonets Karelians and the other immigrants, depicting them as less relatable as Finns than the others. He by no means questioned the kinship between Finns and Olonets Karelians but admitted that he felt "like a stranger, only understanding half of their most peculiar language" (LCMH 731 (3:1:13)). To be able to communicate with them, he told Hakulinen that he needed to use "Russki" and interpreters (LCMH 731 (3:1:13)). Russian is present here, too, but not necessarily as influential as Finnic culture. Instead, the Olonets Karelians in Haavio's letters could be assumed to have been able to speak Russian-at least to some extent—as it was common among the Finnic people living near Saint Petersburg/Petrograd. These people were in relatively regular contact with the city, particularly when it came to trade and work opportunities (Engman 2003, pp.1115). Although not commending Olonets Karelians or honouring them like the Ingrians, Haavio did not refer to them in particularly negative terms either. He recognized them as relevant informants for the task of recording Finnic folklore, but did not idealize them as particularly exemplary representatives of Finnishness. 
The accounts of the Olonets Karelians nuances my earlier statement about the folklorist's persona as consisting of a tight entanglement of anti-Russian, nationalist ideology and the actual study of Finnic folk culture. The political anti-Russian element is clearly visible as inherent in Haavio's and Enäjärvi's descriptions of the locals, both during their propagandaladen journey in 1923 and Haavio's collection journey in 1921. Haavio's descriptions of the Olonets Karelians, in turn, illustrate a proportionately neutral mapping and collection of Finnic culture. This indicates that these two elements of the folklorist's persona-the-the nationalist agenda and the scholarly mapping of culture-could be activated at the same time, but a scholar could also emphasise either one separately. In other words, the two would not constitute one symbiotic entanglement but two salient, though often co-acting, elements of the persona.

\section{AUTHENTIC FOLK CULTURE}

As stated in the introduction, one of the most important aims of folklore studies was to collect, preserve and analyse a national folk culture that was as authentic as possible. Authentic culture was considered archaic, national, and original. The folklorists were part of that culture, as it was their heritage, but they were also in another world: The folklorists were modern and, though nationalistically minded, international (Anttonen 2005, pp.28, 49, 53-54, 90; Bendix 1997, p.35). According to Bendix, the notion of authenticity is crucial in gaining authority in folkloristics. When information is claimed as authentic, it legitimizes the scholar as a (scientific) expert (Bendix 1997, pp.7, 46, 49, 54, 67). In the following section, I discuss how the students used the notion of authenticity in their writing and how they, by doing so, repeated models of being a folklorist, or a folklorist's persona.

As much as the collecting and studying of authentic folklore was an act of building the nation, it was also an act of rescue. The old, original national folk culture was understood to be disappearing due to modernization. The best-preserved folklore was thought to be found in rural areas, among illiterate people who had not moved and had been in as little contact as possible with the outside world (e.g. Vakimo 2001, p.26). Symptomatically, Enäjärvi and Haavio always added upbeat comments when they wrote about finding old information to collect. Overall, all descriptions of people who could offer folklore information were positive (LCMH 731 (3:3:1); LCMH 736 (8:5:6); LCEEH 785 (13:10:25); MCEEH 5, 7.6.1921; Eskola 1999, pp.177, 179). Similar to how positively persons of rank were described, the informants were mostly portrayed with valued virtues as those assigned to people in general but with the exclusion of any negative features. Only once did Haavio add some more gloomy notes on such a situation, interposing that "when one crone sang 9 hours without breaks, I started having some other feelings than happiness too." (Eskola 1999, p.181).

The use of the term, "crone", identifies a second feature usually connected to finding authentic information: the collectors were primarily in search of informants who were as old as possible. There was a consensus among scholars that old people usually best filled the role of carriers of authentic folklore, as described above, even to the extent that they might have rejected good informants due to their young age. Enäjärvi and Haavio wrote in the exact manner as research has identified as typical for the folklorists' approach to old informants: they wrote appreciatively about the elderly, especially if they thought that the informant was particularly clear in thought (LCEEH 785 (13:10:21); Eskola 1999, pp.177-179; compare Vakimo 2001, p.25; Keinänen 2004, pp.95, 99; Skott 2008, p.146).

The students also celebrated archaism in their writings about collecting dialects. The feelings could be put into words in various ways. Enäjärvi, for example, told Lauri Hakulinen on her tour of Karelia that there was so much language material "that it would titillate someone 
like E. A. T." [assumingly the linguist E. A. Tunkelo] (LCEEH 764 (1:9:1)). Haavio described excitedly about finding informants with distinct dialects, pure from interference of other dialects and languages, living relics from an ancient past, or reminding him of the Finnish national poetic epos Kalevala (LCMH 730 (2:3:15); LCMH 731 (3:3:1)). Talking with Bendix, this can be interpreted as the students demonstrating that they knew what material was desirable and placed themselves in a position to evaluate what was authentic folklore and dialect and thereby legitimizing themselves as scholars.

Lotte Tarkka has shown that the collectors marked their positions in relation to the informants by making sure they were in charge of deciding what information was of scholarly interest and how much it was worth, measured in rewards paid to the informants (Tarkka 1989, p.248; compare with Clifford 1984, p.132). This is exemplified in Haavio's presentation of his encounter with a troubadour. At first glance, the old man had given an impression of Väinämöinen, the hero in the Finnish folklore epic Kalevala: white-haired, ancient, stiff in posture, wearing birchbark lapti shoes and carrying a kantele-zither. On Haavio's inquiry, the man had assured him that he indeed knew old folksongs. Disappointingly, the man turned out to know only one song that Haavio deemed relevant and the song was not so rare (Eskola 1999, pp.179-182; LCMH 731 (3:3:1)).

Following Tarkka, the man in question had not complied with the collectors' expectations and view of order. He had given an account of himself as a collector's perfect find but lacked or declined to deliver the desired knowledge. Possibly, the man had not staged his authenticity but only stumbled into the situation due to chance or Haavio's misjudgement. However, rural people were often well-informed about the travelling collectors, particularly because the collectors often followed the same trails. As a result of this awareness, locals often could try more or less actively to offer their knowledge to them (Tarkka 1989, p.248; Kallio 2013, pp.58-60). Karelian rune singers were aware of the popularity of their singing and offered to perform for a fee. According to Tarkka, this was a threat to the collectors' authority and so the collectors tried to counteract it. There was a consensus among the organisers of collections that informants had a right to be paid a minor reward for their information, but also that the collectors were the ones assigning the value and setting the prize. The singers performing for larger audiences for money could, for example, face collectors' smear campaigns, where their information was claimed untrustworthy (Tarkka 1989, p.248; compare Torgovnick 1990, p.9). The old man in Haavio's letters could be interpreted as a singer who tried to take an active part in the knowledge production of Karelian folklore but was dismissed as a bad informant by the collector.

\section{WRITING A FOLKLORIST'S PERSONA}

When the students wrote about the rural people, they simultaneously wrote about themselves: By defining and describing their objects of study - the rural, traditional Finnish and Finnic people-they also defined themselves as folklorists. Since the primary aim of folklore research of the 1920s was to investigate the scholars' own national heritages-in the Finnish scholars' case, the Finnish-related cultures-they needed to identify themselves to some degree with their informants. This need for identification led scholars in part to write idealistically about the national landscape and people with traditional livelihoods.

The folklorist's persona was built on both an identification with their objects of study and a distance from them. Enäjärvi and Haavio claimed scholarly authority by marking their differences from the locals and their belonging in their discipline. One strategy they used was to label some locals as primitive, a state of being that can only be labelled by one who considers 
him- or herself civilised. Similarly, describing someone as smart or enlightened simultaneously establishes one's own knowledge in what counts as such. The students also demonstrated an awareness of their discipline's jargon by using it to describe landscapes and people. Moreover, they manifested their professional knowledge of their objects of study by pointing out observations of what they considered alien influences on Finnish culture.

The students used their objects of study to position themselves as scholars. In addition to the describer and the described, the intended reader also has a function in this persona formation. In most of the cases that I have used as examples in this paper, the intended reader was a student friend, though some letters were sent to family and some accounts were written in private diaries. The various intended readers can be interpreted as shaping different sides of the persona. The letters to student friends offered a playground where students could try out and negotiate ways of describing the objects of study within a shared scholarly field. The similar content in the letters home show that the students also portrayed themselves and their objects of study in the same way outside the scholarly community. The private diary notes further illustrate how a scholarly persona differs from a professional role or self-fashioning; these private diary notes are also a useful tool for investigating how the folklorist persona worked to shape scholars' personal understanding of themselves.

\section{WORKS CITED}

Anttonen, P 2012, 'Oral Traditions and the Making of the Finnish Nation', in T Baycroft \& D Hopkin (eds), Folklore and Nationalism in Europe During the Long Nineteenth Century, Brill, pp. 325-350.

Anttonen, P 2005, Tradition Through Modernity. Postmodernism and the Nation-State in Folklore Scholarship, Finnish Literature Society, Helsinki.

Apo, S, Stark-Arola, L \& Nenola, A (eds) 1998, Gender and Folklore. Perspectives on Finnish and Karelian Culture, Finnish Literature Society, Helsinki.

Baycroft, T 2012, 'Introduction', in T Baycroft \& D Hopkin (eds), Folklore and Nationalism in Europe During the Long Nineteenth Century, Brill, pp. 1-10.

Bendix, R 1997, In Search of Authenticity. The Formation of Folklore Studies, University of Wisconsin Press, Madison, Wis.

Boon, JA 1982, Other Tribes, Other Scribes. Symbolic Anthropology in the Comparative Study of Cultures, Histories, Religions and Texts, Cambridge University Press, Cambridge.

Bosch, M 2013, 'Persona and the Performance of Identity Parallel Developments in the Biographical Historiography of Science and Gender, and the Related Uses of Self Narrative', L'Homme, vol. 24, no. 2, pp. 11-22.

Butler, J 1999, Gender Trouble. Feminism and the Subversion of Identity, Routledge, New York.

Carson, C 2001, 'Objectivity and the scientist: Heisenberg rethinks', Science in Context, vol. 16, no. $1-2$, pp. 243-269.

Clifford, J 1984, 'Power and Dialogue in Ethnography. Marcel Griaule's Initiation', in GW Stocking (ed), Observers Observed. Essays on Ethnographic Fieldwork, University of Wisconsin Press, Madison.

Clifford, J \& Marcus, GE (eds) 1986, Writing Culture. The Poetics and Politics of Ethnography. a School of American Research Advanced Seminar, University of California Press, Berkeley.

Condren, C, Gaukroger, S \& Hunter, I 2006, 'Introduction', in The Philosopher in Early Modern Europe. The Nature of a Contested Identity, Ideas in Context, Cambridge University Press, Cambridge.

Cusack, T 2001, 'A "Countryside Bright with Cosy Homesteads". Irish Nationalism and the Cottage Landscape', National Identities, vol. 3, no. 3, pp. 221-238. 
Daston, L \& Sibum, HO 2003, 'Introduction: Scientific Personae and Their Histories', Science in Context, vol. 16, no. 1-2.

Dundes, A 1980, Interpreting folklore, Indiana University Press, Bloomington.

Engman, M 2003, Dagligt liv i S:t Petersburg. Bland kejsarens finländska undersåtar, SLS, Helsingfors.

Eskola, K 1999, Kahden. Martti Haavion ja Elsa Enäjärven päiväkirjat ja kirjeet 1920-1927, WSOY, Porvoo \& Helsinki.

Eskola, K 'Elsa Enäjärvi-Haavio (1901-1951)', Klassikkogalleria. Feministisiä ajattelijoita 16001950-luvuilta, retrieved March 10, 2017, from

<http://www.helsinki.fi/sukupuolentutkimus/klassikkogalleria/enajarvi/index.htm>.

Fabian, J 2002, Time and the Other. How anthropology makes its object, Columbia University Press, New York.

Fabian, J 2006, 'The other revisited. Critical afterthoughts', Anthropological Theory, vol. 6, no. 2, pp. 139-152.

Fewster, D 2011, “"Braves Step out of the Night of the Barrows”. Regenerating the Heritage of Early Medieval Finland', in RJW Evans \& GP Marchal (eds), The uses of the Middle Ages in modern European states. History, nationhood and the search for origins, Palgrave Macmillan, New York.

Finnish Literature Society, Literary archives, Letter collection of Elsa Enäjärvi-Haavio (LCEEH). $764,785$.

Finnish Literature Society, Literary archives, Letter collection of Martti Haavio (LCMH). 730, $731,736,758$.

Finnish Literature Society, Literary archives, Manuscript collection of Elsa Enäjärvi-Haavio (MCEEH). 5. Diaries, 'Diary of 1923', 'Vb Kesä 1921'.

Finnish Literature Society, Literary archives, Manuscript collection of Martti Haavio (MCMH). 5.1 Diaries.

Finto: KOKO: ortodoksinen kirkko', retrieved March 9, 2017, from <http://finto.fi/koko/fi/page/p12457>.

Forsman, J, Wecksell, JA, Havu, I \& Salovaara, H (eds) 1925, Pieni tietosanakirja. 1. osa. A Isonzo, Otava, Helsinki.

Garberding, P 2012, "'There are dangers to be faced". Cooperation within the International Association of Folklore and Ethnology in 1930s Europe', Journal of Folklore Research, vol. 49, no. 1, pp. 25-71.

Häyrynen, M 2000, 'The Kaleidoscopic View: The Finnish National Landscape Imagery', National Identities, vol. 2, no. 1, pp. 5-19.

Junkala, P, Kiuru, E, Löfström, J, Lönnqvist, B \& Sääskilahti, N (eds) 1998, 'Toinen' sivilisaatio. Arkielämä, sivilisaatio ja kansankulttuuri Suomessa noin 1500-2000, University of Jyväskylä, Jyväskylä.

Kallio, K 2013, Laulamisen tapoja. Esitysareena, rekisteri ja paikallinen laji Länsi-Inkeriläisessä kalevalamittaisessa runossa, University of Helsinki, Helsinki.

'Karjala' 2015, Institute for the Languages of Finland, retrieved April 10, 2017, from <https://www.kotus.fi/kielitieto/kielet/karjala>.

Keiho, H 1994, 'Mikä on ryssä-sanan synty?', Hiidenkivi. Suomalainen kulttuurilehti, p. 44.

Keinänen, M-L 2004, 'Metsäsuomalaisen kulttuurin renessanssi ja suomalaiset tutkijat', in P Laaksonen, S Knuuttila, \& U Piela (eds), Kenttäkysymyksiä, Finnish Literary Society, Helsinki, pp. 91-110.

Koski, K 2011, Kuoleman voimat. Kirkonväki suomalaisessa uskomusperinteessä, Finnish Literature Society, Helsinki.

Lähteenmäki, M 2009, Maailmojen rajalla. Kannaksen rajamaa ja poliittiset murtumat 19111944, Finnish Literature Society, Helsinki.

Lilja, A 1996, Föreställningen om den ideala uppteckningen. En studie av idé och praktik vid traditionssamlande arkiv. Ett exempel från Uppsala 1914-1945, Dialekt- och folkminnesarkivet [distributör], Uppsala.

Loomba, A 2002, Colonialism/postcolonialism, Routledge, London. 
Majamaa, R 'Haavio, Martti (1899-1973)', Biografiskt Lexikon för Finland, retrieved March 10, 2017, from <http://www.blf.fi/artikel.php?id=703>.

Nevalainen, P 1991, 'Inkerinmaan ja inkeriläisten vaiheet 1900-luvulla', in P Nevalainen \& H Sihvo (eds), Inkeri. Historia, kansa, kulttuuri, Finnish Literature Society, Helsinki, pp. 234-299.

Nyström, S 2013, Poikkeusajan kaupunkielämäkerta. Helsinki ja helsinkiläiset maailmansodassa 1914-1918, University of Helsinki, Helsinki.

Ó Giolláin, D 2000, Locating Irish Folklore. Tradition, Modernity, Identity, Cork University Press, Cork.

Paul, H (ed.) 2016, Low Countries Historical Review. Theme issue on Scholarly Personae.

Paul, H 2017, 'What Defines a Professional Historian? A Historicizing Model', Journal of the Philosophy of History, vol. 11, no. 2, p. 229.

Pöysä, J 2004, 'Historian etnografia Vienassa', in Kenttäkysymyksiä, Kalevalaseuran vuosikirja, Finnish Literature Society, Helsinki, pp. 25-72.

'Russki' 2018, Oxford Dictionaries, retrieved March 7, 2018, from $<$ https://en.oxforddictionaries.com/definition/russki>.

Sääskilahti, N 1998, 'Autenttinen kansankulttuuri?', in P Junkala (ed), 'Toinen' sivilisaatio. Arkielämä, sivilisaatio ja kansankulttuuri Suomessa noin 1500-2000, Jyväskylän yliopisto, Jyväskylä, pp. 64-78.

Said, EW 2000, Orientalism, Ordfront, Stockholm.

Seljamaa, E-H 2008, 'Remarks on the Historic-geographic Method and Structuralism in Folklore Studies. The Puzzle of Chain Letters', Journal of Ethnology and Folkloristics, vol. 2, no. 1, pp. 83-98.

Sievänen-Allen, R 1993, Tyttö venheessä. Elsa Enäjärvi-Haavion elämä 1901-1950, WSOY, Porvoo \& Helsinki.

Skott, F 2008, Folkets minnen. Traditionsinsamling i idé och praktik 1919-1964, Institutet för språk och folkminnen i samarbete med Göteborgs universitet, Göteborg.

Spring, U 2001, 'Imagining the Irish and Norwegian Peasant around 1900. Between RePresentation and Representation', Historisk Tidsskrift (Norway), vol. (80) 2001:1, pp. 75-99.

Tai, C \& Dongen, J van 2016, 'Anton Pannekoek's Epistemic Virtues in Astronomy and Socialism. Personae and the Practice of Science', BMGN - Low Countries Historical Review, vol. 131, no. 4.

Tarkka, L 1989, ‘Karjalan kuvaus kansallisena retoriikkana. Ajatuksia karelianismin etnografisesta asetelmasta', in Runon ja rajan tiellä, Finnish Literature Society, Helsinki, pp. 32-46.

Torgovnick, M 1990, Gone primitive. Savage intellects, modern lives, University of Chicago Press, Chicago.

Vakimo, S 2001, Paljon kokeva, vähän näkyvä. Tutkimus vanhaa naista koskevista kulttuurisista käsityksistä ja vanhan naisen elämänkäytännöistä, Finnish Literature Society, Helsinki.

Virtanen, M 2001, Fennomanian perilliset. Poliittiset traditiot ja sukupolvien dynamiikka, Finnish Literature Society, Helsinki.

Wichmann, Y et.al. 1922, Tietosanakirja. Tietosanakirja-osakeyhtiö, Helsinki. 